Discussion Paper No. 799

\title{
REVITALIZING THE JAPANESE ECONOMY BY SOCIALIZING RISK
}

\author{
Charles Yuji Horioka \\ Reiko Kanda
}

December 2010

The Institute of Social and Economic Research

Osaka University

6-1 Mihogaoka, Ibaraki, Osaka 567-0047, Japan 


\title{
Revitalizing the Japanese Economy by Socializing Risk
}

\author{
Charles Yuji Horioka \\ Professor of Economics, Institute of Social and Economic Research, Osaka University \\ and \\ Reiko Kanda \\ Senior Director of Research Division, National Institute for Research Advancement (NIRA)
}

December 5, 2010

\begin{abstract}
The almost continuous stagnation of the Japanese economy for the past two decades has had an adverse impact on Japanese households from at least three perspectives: A decline in the standard of living, an increase in risks and uncertainties relating to livelihood, employment, old age, etc., and an increase in income inequality. The majority of economists and policymakers focus their attention on the increase in income inequality. The research discussed here, however, focuses on the increase in risk and uncertainty among households and individuals. Based on this research, we propose a shift to a policy regime centering on the socialization of risk, which will make possible a transition from a society in which individuals bear excessive risks to one in which risk is shared equitably by society as a whole.
\end{abstract}

Key words: Japanese economy; Policy regimes; Liberal regime; Social democratic regime; Conservative regime; Economic risks; Risk-coping mechanisms; Risk sharing; Socialization of risk; Social welfare; Redistribution; Government expenditures; Income gap; Income disparities; Income inequalities; Discrimination; Child care; Nursing care; Employment; Work-life balance; Bankruptcy; Financial products; Poverty; Collectivist entities; Policy recommendations

Journal of Economic Literature classification numbers: G20, H11, H50, I38, J08, J70, P10, P51

Forthcoming in The Japanese Economy (Armonk, N.Y.: M. E. Sharpe, Inc.), vol. 37, no. 3 (Fall 2010), pp. 3-35.

English translation of: Charles Yuji Horioka and Reiko Kanda, "Souron," in National Institute for Research Advancement (NIRA), ed., 'Shijou ka, Fukushi ka' wo Toinaosu-Nihon Keizai no Tenbou wa 'Risuku no Shakai ka' de Hiraku (research report) (Tokyo, Japan: National Institute for Research Advancement (NIRA), March 2010), pp. 1-24. Translated by Stacey Jehlik.

Acknowledgements: We are grateful to Naohito Abe, Shuhei Aoki, David Flath, Kimiya Nakagomi, Naoki Shimoi, and Kengo Yasui for their valuable comments.

Corresponding author: Charles Yuji Horioka, Institute of Social and Economic Research, Osaka University, 6-1, Mihogaoka, Ibaraki, Osaka 567-0047, JAPAN. Telephone: 81-6-6879-8586. Facsimile: 81-6-6879-8575. Email: horioka@iser.osaka-u.ac.jp 


\section{The Importance of This Study}

\section{Background}

The Japanese economy has been at a standstill for about twenty years and seems unable to break free of its prolonged stagnation. This has had a negative impact on households in at least three ways. First, the prolonged stagnation has reduced the standard of living of the majority of households by causing the stagnation of their disposable incomes. Second, it has increased the uncertainties and risks associated with everyday living, employment, aging, and having children, thereby reducing household spending. Third, because the burden of the prolonged stagnation has not been borne equally by all households, it has increased the income gap between the so-called "winners" and "losers." Japan's inability to prevent an economic slowdown of such unprecedented scale and duration and thus its inability to prevent the various negative consequences for households suggests that there is some fundamental deficiency in Japanese economic, social, and political structures (particularly Japan's welfare and employment systems, or more broadly speaking, its policy regime). Many economists, policymakers, and pundits focus on the third of the three problems listed above (the increase in the income gap), but the purpose of this research project was to focus on the second issue (the increase in uncertainty and risk) and to investigate what changes need to be made in Japan's policy regime to solve this problem. In particular, we considered what kind of policy regime is needed to shift from a society in which individuals shoulder excess risks themselves to one in which risks are borne more equitably by society as a whole (that is, to achieve the so-called "socialization of risk").

\section{Preparing for economic risks}

There is an old proverb that says "Be prepared and you will have no regrets." This suggests that if you prepare for unfortunate events that might occur in the future, you will be able to rest easy even if they come to pass. But what is the best way to prepare for such events? That is the theme of this research project. People face many kinds of risks and uncertainties, including global warming, resource depletion, water shortages, infectious diseases, earthquakes, unemployment, and accidents. This research project focuses on economic risks, compares Japan's policies relating to risk preparation to those of other countries, and makes suggestions regarding the future path Japan should follow. What has become quite clear is that, in Japan, risks are not borne equitably by everyone; that is, risks are not "socialized." It is therefore important that systems be designed so that risks can be socialized.

Going beyond the income gap debate

In recent years, the growing income gap has become a significant social problem, and widespread debate over this issue is often couched in terms of "winners" and "losers." Implicit in this discussion is the assumption that "winners" will always be "winners" but that once someone becomes a "loser," it is very difficult for them to ever become a "winner." The sense of being a "winner" breeds a sense of entitlement, while the sense of being unable to escape from being a loser results in envy. In a society where there is a mix of entitlement and envy, it is difficult for risks to be shared equitably by everyone.

However, with the accelerated pace of social change, today's winners may become tomorrow's losers, and vice versa. If Japan loses its status as an economic superpower, everyone is in danger of becoming a "loser." It is precisely at times like these that the discussion needs to go beyond 
the income gap debate and to focus instead on how to build structures so that risks can be shared by society as a whole.

The irrationality of the shouldering of economic risks by individuals

When thinking about preparing for risks, it is important to realize that it is not at all rational for individuals to bear the economic risks of unemployment, wage reductions, bankruptcy, etc., by themselves. For example, suppose there is a person who is currently earning an income that allows him to support himself but who is plagued with the uncertainty that he might eventually become unemployed. If unemployment insurance is not available, that individual will have to work feverishly while he can in order to prepare for the possibility of losing his job. However, if he works too hard, he may become physically ill and unable to work. Also, in a world with no public pension system, because an individual does not know how long he is going to live, he will have to spend his entire life saving money, and may end up dying without ever having been able to enjoy his retirement.

It is better for such risks to be shared by society than for individuals to have to bear the entire risk themselves. In the former example, if society has a fully functioning unemployment insurance system, the individual will not have to work himself to the point of physical collapse. In the latter example, if society has a public pension system, benefits will be paid that will allow the person to enjoy his retirement without having to work. These are two systems that already exist, but they provide examples of how risk sharing by society as a whole (the socialization of risk) can produce a greater sense of security. Today, there is a need to find ways to reconfigure society so as to socialize the risks we all face.

The need to discuss policy regimes

Socializing risk through social insurance systems is only one part of the socialization of risk. It would be inappropriate to discuss the socialization of risk only in the context of welfare policies. The socialization of risk spans a broader range of policies that include not only policies to prepare for predictable risks and policies for dealing with risks after they occur but also mechanisms for ensuring that risks are shared equitably from the outset and for extracting efforts to ensure that risks are not exacerbated. For this reason, this study interprets the socialization of risk more broadly to include the policy regime (i.e., the nation's system of policies as a whole). Rather than looking only at welfare policies and trying to cut and paste policies in a patchwork sort of way depending on what is needed at the time, it is important to discuss the question of how the policy regime itself should be structured.

\section{What Can Japan Learn from the Three Policy Regimes?}

\subsection{Risk Coping Mechanisms in the Three Policy Regimes}

Mechanisms for socializing risk can be broadly divided into two categories. The first are those that make the fullest possible use of the market mechanism. Bundling the risks of many people together makes it possible to pool risk, measure that risk, and then sell it on the market, which in turn makes it possible for investors to voluntarily shoulder that risk. The second are those that are implemented by the government (generally referred to as income redistribution). There are concerns that government intervention invites moral hazard. For example, generous 
unemployment benefits may reduce the efforts of workers to avoid unemployment or may lengthen the duration of unemployment spells.

The social scientist Esping-Anderson (1990, 1999) emphasizes that the welfare and employment systems of the advanced nations (hereafter referred to as "policy regimes"), can be broadly categorized into three types. First, he classifies a nation's policy regime by whether the nation emphasizes resource and wage allocation through the market mechanism or whether it emphasizes income redistribution by the government. Next, he classifies nations that emphasize income redistribution into those whose redistributive policies are supplementary and limited and those that are universal and comprehensive.

More specifically, he classifies them as follows (see Aoki, Shimoi, and Nakagomi (2010), section 2):

(1) Liberal (or residual) regimes (welfare states) respect the distribution of resources and wages via the market mechanism and minimize redistribution via government intervention. The best examples of such regimes are the Anglo-Saxon countries. In these countries, while economic performance can be expected to be higher, there are also likely to be larger economic disparities and a larger proportion of poor people.

(2) Conservative (or corporatist) regimes (welfare states) emphasize income redistribution policies but leave that function to the mutual assistance of traditional collectivist entities such as families and companies. Government intervention is limited and merely supplements the role of traditional collectivist entities. The best examples of such regimes are the countries of continental Europe.

(3) Social democratic regimes (welfare states) emphasize income redistribution policies but leave that function primarily to the government. In such regimes, the proportion of individuals who benefit from redistributive policies is relatively high, making it is a universal or comprehensive system. The best example of such regimes are the countries of northern Europe.

\subsection{Considerations for Japan}

According to social scientists like Esping-Andersen, Japan has developed a system with characteristics of both liberal and conservative regimes. It has liberal characteristics insofar as the government plays only a weak redistributive function, but it has a conservative character insofar as involvement by the government in the redistribution system is supplemental and limited and insofar as welfare functions, such as childcare and long-term care of the aged, are left to families. Given this duality in its policy regime, we will discuss what Japan should learn from the three types of policy regimes going forward.

\section{Liberal Regimes}

Liberal regimes emphasize risk adaptation by the individual

Liberal regimes place emphasis on resource distribution through the market mechanism and believe that income redistribution by the government should be kept to a minimum. Therefore, liberal regimes have to address the issue of how to prevent risks using market mechanisms 
without having to rely on a social welfare system that provides the ultimate safety net for individuals.

One of the characteristics of liberal regimes is that they provide employment opportunities to as many people as possible and reduce the risk of unemployment by improving market efficiency and making the achievement of high economic growth the ultimate goal. Arai (2002) argues that "American society is blessed with abundant employment opportunities such that anyone with the desire to work can find a job. Workers are then covered by social insurance, and thus are protected against the various risks they might encounter in the course of life." If a society emphasizes the desire to work, then it is important to adopt policies aimed at relaxing market regulations to ensure employment opportunities and promoting competition in the market. Also, the achievement of small government by restricting the scale of government expenditures is an important issue in liberal regimes given the emphasis on keeping taxes on citizens as low as possible and avoiding disincentives against working.

Another characteristic of liberal regimes is that they ensure that risks are shared among people through the use of financial products offered by private financial institutions such as insurance and loans. This approach is highlighted by Shiller's proposal, discussed in Aoki, Shimoi, and Nakagomi (2010). For example, the issuance of sub-prime loans, or home loans to low-income earners, allowed low income earners with a high risk of default to borrow money to purchase a home. This is an example of how individual risks can be bundled, divided into tiers based on the level of risk, and then sold to investors, thereby allowing risks to be shared between the borrowers and lenders through the intermediation of financial institutions.

As is evident from these two characteristics, liberal regimes do not rely on benefits awarded through redistributive policies but instead focus on the creation of a society where people can cope with risks on their own. For this regime to succeed, it is important to build a well functioning market. Of course, in reality, the risk coping mechanisms discussed above do not eliminate all risk, and in many cases debtors who take out loans from financial institutions are unable to repay those loans. However, even in these cases, under American bankruptcy laws, there are sufficient systems in place to enable individuals who have gone bankrupt to rebuild their financial lives. The fact that declaring bankruptcy is an option shows that personal bankruptcy laws function as a de facto safety net and support individual efforts to start afresh.

Regarding bankruptcy, Ferguson (2008) notes that any American can declare bankruptcy under Chapter 7 (liquidation) or Chapter 13 (adjustment of debts of individuals with regular income) of the US Bankruptcy Code. He writes: "Rich and poor alike, people in the United States appear to regard bankruptcy as an 'unalienable right' almost on a par with 'life, liberty and the pursuit of happiness.'"

Note: The US personal bankruptcy system ${ }^{1}$

There are two types of procedures for declaring personal bankruptcy in the US, and the debtor can decide which of the two he wants to pursue. The first is bankruptcy under Chapter 7 of the Bankruptcy Code, in which case all of the discharged assets are confiscated (except for exempt assets, which differ by state), but unsecured debts are eliminated and future income is excluded from the claimant's repayment obligations. The other option is bankruptcy under Chapter 13 of the Bankruptcy Code, in which case the debtor can keep all of his assets, but some of his future income must be used to repay a portion of his unsecured debt.

\footnotetext{
${ }^{1}$ For more on the personal bankruptcy system in the US, see Bertola et al. (2006) and Yamada (2006).
} 
The major difference between the US and Japan is the value of owned assets that are excluded at the time of bankruptcy. In the US, assets over and above a certain limit are subject to exclusion, but in Japan, they are not. In more than half of the States, $\$ 10,000$ or more in real estate is subject to exclusion, while in Japan, the only amounts excluded are cash to cover three months’ worth of living expenses (¥990,000) and minimal amounts of food and clothing.

In the US, however, because of the options provided by Chapter 7 of the Bankruptcy Code, many felt that the number of bankruptcy claims being filed was increasing even in cases where debt repayment was possible. As a result, some revisions were made to the US Bankruptcy Code in 2005 to make it more difficult to file Chapter 7. New conditions were added to the steps debtors must take before filing such as a means test and a credit counseling requirement, and it became possible to reject bankruptcy applications in some cases.

The powerlessness of the individual in Japan

What are the problems with Japanese policies from the perspective of a liberal regime? First, Japan has various types of regulations that impede efficiency. Institutional and regulatory reforms have been implemented in Japan since the 1980s, and there has been a long-term trend toward deregulation, but the OECD's regulation index ${ }^{2}$ suggests that the Japanese market is still subject to stronger regulations than the US market and has lower entry rates as well as exit rates of firms. Even in the area of employment regulation, Japan has stronger regulations relating to mass layoffs than the US, and stronger employment protection by companies. ${ }^{3}$ Of course, a total lack of layoff regulations would be problematic from the point of view of employee protection, but stimulating corporate competition and creating an economy that is flexible and competitive by reducing the costs relating to the entry and exit of firms and reducing employment costs are essential to reducing risk.

A second problem is that Japanese financial markets are underdeveloped from the perspective of risk sharing. In Japan, the development of non-recourse loans ${ }^{4}$ and reverse mortgages ${ }^{5}$ has been sluggish, and the mortgage-backed securities market, which allows for broader risk sharing, is quite immature. Even with regard to the management of financial assets, the low return on household assets, which in turn is due to the high share of bank deposits in household portfolios, suggests that individuals are not being offered investment opportunities that provide adequate insurance against future risks.

Thus, Japan's problem from the perspective of a liberal regime is that the mechanisms currently in place are not adequate to enable individuals to cope with risks. The existence of competition-restricting systems and regulations that cripple economic growth and the lag in the development of financial markets restrict economic growth and increase the economic risks that individuals must bear on their own. Individuals who have taken risks and lost are likely to fall

\footnotetext{
${ }^{2}$ As discussed in Aoki, Shimoi, and Nakagomi (2010), section 2, the OECD Indicators of Product Market Regulation (PMR) show that Japan's PMR is 1.11 versus 0.84 in the US (both figures from 2008), and Japan's employment regulation indicator is 1.73 versus 0.85 in the US (also figures from 2008). In both cases, Japan is found to have stronger regulations than the US.

${ }^{3}$ See Aoki, Shimoi, and Nakagomi (2010), section 3, Box 2.

${ }^{4}$ This is a non-retroactive loan such that when a person becomes unable to repay a loan, only the assets used as collateral can be used for debt recovery. This is a common type of loan in the US, but in Japan retroactive loans that require additional collateral or a personal guarantee are more common.

${ }^{5}$ This is a type of loan that uses residential assets as collateral. When the borrower dies (or moves), the collateral is sold and the loan is repaid in one lump sum. This type of loan is often used by elderly people who have little cash income.
} 
into a situation in which they have no choice but to assume all the risks themselves because the system for personal bankruptcy is not sufficiently generous.

The shift to a liberal regime would require strengthening competitiveness policies and private risk sharing functions

The shift to a liberal regime would require transitioning to a policy regime that emphasizes economic efficiency. Changing the Japanese system would require thorough deregulation of corporate activities and efforts to stimulate corporate competition by lowering the costs incurred by firms when entering or exiting the marketplace.

At the same time, it is necessary to offer incentives to encourage individuals to acquire adequate risk coping mechanisms and to prepare a safety net for those for whom risks become a reality. First, it is essential to rethink the employment protection systems in the Japanese labor market, which place too much emphasis on the needs of full-time employees. It is also essential to motivate workers by making it possible for them to choose work patterns that suit them best from among a diverse range of options. Second, there is a need to rethink the current risk sharing functions of Japanese financial institutions, which do not provide individuals or companies with adequate means for procuring capital or adequate access to investment and insurance opportunities. Third, a society must be created in which individuals can recover from bankruptcy and easily change jobs so that they can have a second chance to succeed. This requires that the costs of bankruptcy and of changing jobs be reduced.

\section{Social Democratic Regimes}

Social democratic regimes distribute risks equitably throughout society

In social democratic regimes, in which the equality of individual incomes is the ideal outcome, there is heavy emphasis on income redistribution by the government. The achievement of income equality through income redistribution, as corroborated by the Gini coefficient and the poverty rate, is discussed in Aoki, Shimoi, and Nakagomi (2010), section 4. However, how can the actualization of risk be prevented under a social democratic regime? Here we will look at this question from the perspective of the contribution of government expenditures to the risk coping ability of each generation and the fairness of the labor market.

Figure 1 shows redistribution-related government expenditures as a percentage of GDP for each generation (the elderly, working age adults, and children) The expenditures that are allocated to each generation are as follows: educational expenditures are allocated to children, family-, employment-, and welfare-related benefits and expenditures to working-age adults, and public pension benefits to the elderly. A comparison of the breakdown of government expenditures by generation in Sweden, which has a socialist democratic regime, and other developed countries reveals that the share of expenditures on the elderly are lower in Sweden than in Japan, while the shares of expenditures on working-age adults and expenditures on children are much higher in Sweden than in other developed countries including Japan. That is, the Swedish government has an expenditure structure that redistributes enough income to working-age adults and children. Maintaining a balance in the structure of government expenditures across generations effectively lowers the risks that those who are currently working-age adults or children will face in the future. If children are offered a high-quality education and are equipped with the knowledge they need to succeed in contemporary society, 
they are likely to be able to find lucrative work in the future, and if adequate childcare and longterm care services are provided, this will promote the employment of working-age adults.

Figure 1: Government Redistribution-related Expenditures by Generation in Selected Countries (2005, \% of GDP)

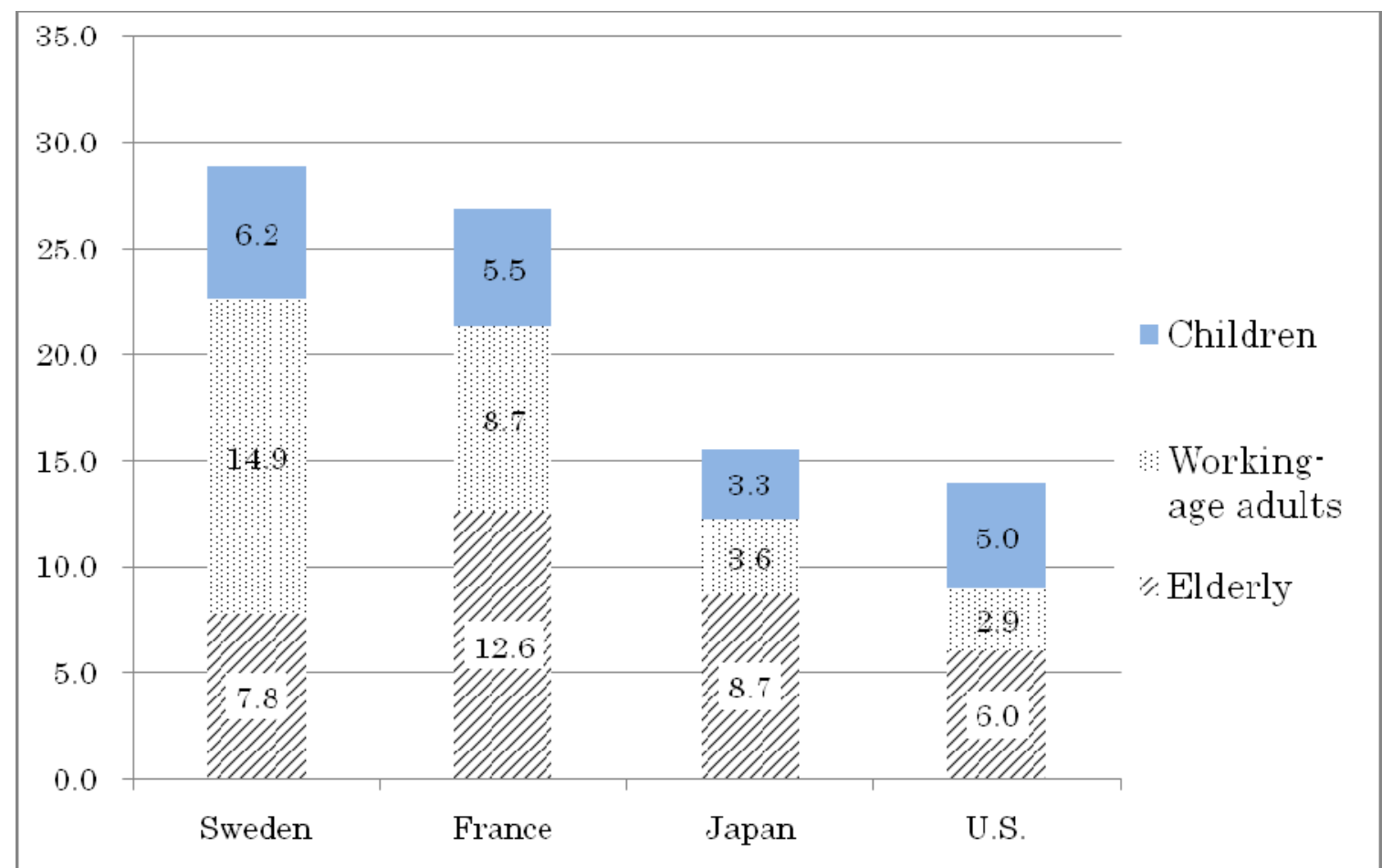

Source: OECD "OECD.stat," "Education at a Glance" (2009).

Note 1: Expenditures on children consist of public education expenditures; expenditures on working-age adults consist of expenditures on the handicapped, families, active labor market policies, unemployment benefits, housing, and long-term care (the provision of residential care or at-home care to the elderly); while expenditures on the elderly consist of public pension benefits.

Note 2: Child care-related expenditures (a component of family-related expenditures) and longterm care-related expenditures benefit children and the elderly, respectively, but they have been included in expenditures on working-age adults because they support the activities of workingage adults.

Note 3: Because it is difficult to break down medical expenditures by age group, they have been omitted here.

We turn next to the fairness of the labor market, which is another hallmark of social democratic regimes. It is important to note that ensuring fairness in the labor market helps improve economic efficiency. The small wage gap between men and women in Sweden has improved the productivity and employment rates of women, which in turn has contributed to an increase in economic growth. Wage disparities between genders dampen the ambitions of women and reduce their productivity because they will exert only as much effort as warranted by 
their low wages. ${ }^{6}$ When women's market wages are lower than those of men, it is a rational choice for women to be responsible for housework while men work outside the home, and thus the labor supply of women is constrained. In other words, setting women's wages at too low a level makes it difficult to extract a level of effort from them that is commensurate with their abilities and thus lowers economic efficiency. By contrast, ensuring a fair labor market is likely to raise economic efficiency. The countries of northern Europe, including Sweden, recognize that fairness and economic efficiency are not mutually exclusive and thus strive to use fairness in the labor market as a way of achieving improvements in economic efficiency.

Needless to say, ensuring the fairness of labor markets will also help reduce the amount of risk borne by individuals. As shown in Table 1, about $60 \%$ of children from single-parent families are living in poverty in Japan, and this figure does not improve even if we focus on single-parent families in which the parent is working. By contrast, in Sweden, the ability to pull oneself out of poverty dramatically improves once one has a job.

The foregoing suggests that extensive income redistribution by the government under social democratic regimes not only corrects income disparities as an outcome but also achieves a fair allocation of risk across generations by allocating redistribution-related government expenditures equitably across generations. Moreover, ensuring fairness in the labor market not only improves economic efficiency but also ultimately achieves a reduction in risk at the individual level. In social democratic regimes, risks are shared equitably across generations, and strengthening the ability of individuals to adapt to risk through a fair labor market prevents the actualization of risk and reduces the costs of income redistribution via social welfare programs.

Table 1: Poverty Rates of Children of Employed and Unemployed Parents (mid-2000s)

\begin{tabular}{|l|l|l|l|l|}
\hline & Sweden & France & Japan & US \\
\hline $\begin{array}{l}\text { Overall childhood } \\
\text { poverty rate }\end{array}$ & $4 \%$ & $8 \%$ & $14 \%$ & $21 \%$ \\
$\begin{array}{l}\text { Parent is single and } \\
\text { unemployed }\end{array}$ & $18 \%$ & $46 \%$ & $60 \%$ & $92 \%$ \\
$\begin{array}{l}\text { Parent is single and } \\
\text { employed }\end{array}$ & $6 \%$ & $12 \%$ & $58 \%$ & $36 \%$ \\
\hline
\end{tabular}

Source: OECD, "Society at a Glance" (2009).

Note: The figures above were calculated from the equivalent disposable incomes of households (disposable income divided by the square root of the number of people in the household). ${ }^{7}$ The poverty line is set at $50 \%$ of median income.

Risks are not shared equitably in Japan

This section highlights the problems with current Japanese policies by comparing them against those of a social democratic regime.

\footnotetext{
${ }^{6}$ Coate and Loury (1993) show theoretically that employment discrimination, which has the effect of reducing the desire of the discriminated population to improve productivity, results in a self-fulfilling prophecy that ends up producing less productive workers. See also Yamaguchi (2008).

${ }^{7}$ For the definition of income, see Foster and d'Ercole (2005).
} 
With respect to the equitable sharing of risk across generations, redistribution in Japan is heavily dominated by the transfer of income from working-age adults to the elderly. Income transfers to working adults in the form of family policies, active labor market policies, and social welfare are limited, as are income transfers to children in the form of education. As a result, it is very likely that risks in Japan are being borne primarily by working-age adults and children.

The most serious problem regarding fairness in the labor market is that there is a discrepancy in worker treatment between male and female employees and between full-time and non-fulltime employees with respect to wages, promotions, and training opportunities. The primary causes of this problem are the lag in childcare and long-term care services, the discriminatory treatment of non-full-time employees, and policies that constrain female employment such as the ordinary and special tax deductions for spouses.

Another problem is that, although Japan's redistributive policies have legal backing, lowerlevel government officials have considerable administrative discretion when deciding the amount of benefits, as is explained in Aoki, Shimoi, and Nakagomi (2010), section 4, and this greatly weakens the effectiveness of such policies.

In sum, the problems with Japan's policies as compared to those of social democratic regimes are that redistributive policies do not ensure that risks are shared equitably across generations, that the absence of fairness in the labor market weakens the efficiency of the economy overall and increases the risks borne by individuals, and that excessive administrative discretion reduces the effectiveness of redistributive policies.

The shift to a social democratic regime requires risk sharing across generations and fair labor market practices

There are many lessons to be learned from social democratic regimes that achieve risk sharing through government redistributive policies. The policies needed to shift to a social democratic regime are as follows:

First, government expenditures need to be reallocated to reduce the risks borne by workingage adults and children. Significant amounts need to be reallocated to childcare and other familyoriented policies, to benefits for unemployed young people, and to investments in the education of young people. In Japan, the institutional risks of the public pension system are currently being shifted to younger generations, but instead the government should introduce an automatic fiscal stabilization mechanism such as the one in place in Sweden and should ensure that everyone, including the generation of people currently receiving benefits, bears his or her fair share of risks.

Second, it is important to make the labor market fair and to ensure that there is no discrimination by gender or employment status. The high proportion of dual-earner households in Sweden reduces the risks borne by households. In Japan as well, because it is common for the spouse to seek employment when household incomes drop, ${ }^{8}$ raising the female employment rate through improvements in childcare and long-term care services is a pressing issue.

Third, for government redistribution to work, government infrastructure needs to be improved so that administrative discretion in government transfer systems can be eliminated and the incomes of individuals can be accurately ascertained for income tax purposes. Japan's social welfare system may appear to be on a par with that of Sweden, but Japan faces the problem of broad discrepancies among individuals in benefits due to excessive administrative discretion.

\footnotetext{
${ }^{8}$ The analysis based on panel data discussed in Abe (2010) shows that in households whose income has declined, income fluctuations are reduced by the spouse obtaining a job.
} 
Fourth, getting the citizenry to agree to bear the burden of these changes will require an increase in government transparency and trust. Achieving this will require the simplification of government structures to clarify the locus of responsibility because, under current conditions, where national, prefectural, and municipal jurisdictions overlap, it is difficult for citizens to know which administrative body is responsible for various functions. Japan should also introduce an ombudsman system to improve oversight functions.

\section{Conservative Regimes}

Collectivist entities function as risk shelters

In conservative regimes, having a family or working for a stable company provides security for the future, but the two pillars that support the risk sharing functions of these two collectivist entities are strict employment regulations on companies and generous redistributive policies focusing on cash benefits such as family allowances.

Employment regulations in the US and Europe include strict termination restrictions that have been shown to prolong unemployment spells of workers and to raise the unemployment rate of younger workers relative to those of middle-aged workers. ${ }^{9}$ When a leftist administration came into power in France in $1997,{ }^{10}$ it tried to mitigate these negative impacts by cutting per capita working hours by introducing the 35-hour work week and by making efforts to reduce the unemployment rate by introducing a work sharing system in which a single job is shared by multiple workers. ${ }^{11}$

The other key component of France's policy regime is family policies. Even in Japan it is commonly known that France provides large cash benefits to its people. Generous family allowances, which were introduced in light of the severe birth rate decline, are intended to promote childbirth, but they also have a disincentive effect on female labor supply. ${ }^{12}$ For this reason, France has recently been promoting female employment and creating an environment in which women can achieve a balance between work and home life by rapidly increasing government subsidies for childcare services, as shown in Table 2. In addition, employmentrelated cash benefits, including unemployment benefits, are also higher in France than in other countries. ${ }^{13}$

Under this kind of conservative regime, the government induces collectivist entities such as companies and families to perform a risk sharing role through a combination of employment policies and family policies.

\footnotetext{
${ }^{9}$ For a survey of studies that analyze the impact of termination regulations on employment risk, see Yasui (2010).

${ }^{10}$ This statement is based on the Japan Institute for Labour Policy and Training (JILPT), Employment Policy Reform in France and Germany: EU Employment Strategies and Policy Transition (JILPT Report No. 15, 2004).

${ }^{11}$ The same report shows that under Aubry II, France's second law relating to the 35-hour work week, companies that reduce working hours to 35 hours per week based on a collective-bargaining agreement are entitled to additional reductions in, or exemptions of, social insurance contributions for low-income workers (p.16).

${ }^{12}$ This issue is discussed in Aoki, Shimoi, and Nakagomi (2010), section 3, but Revillard (2006) also argues that due to changes in the family allowance payments in France (benefits formerly offered to parents with three or more children are now also available to parents with two or more children), the labor force participation of mothers with two children, which had been consistently increasing prior to the adoption of that system, has now leveled off.

${ }^{13}$ See Figure 6 in Aoki, Shimoi, and Nakagomi (2010), section 3.
} 
Table 2: Trends in Cash Benefits and In-kind Benefits in France (as a \% of GDP)

\begin{tabular}{lcccccc}
\hline & 1980 & 1985 & 1990 & 1995 & 2000 & 2005 \\
\hline $\begin{array}{l}\text { Cash benefits (e.g., cash } \\
\text { allowances) }\end{array}$ & 13.8 & 17.5 & 15.6 & 17.1 & 16.6 & 17.5 \\
$\begin{array}{l}\text { In-kind benefits (e.g., } \\
\text { childcare services) }\end{array}$ & 6.9 & 7.9 & 8.8 & 10.3 & 10.1 & 10.8 \\
\hline
\end{tabular}

Source: Organisation for Economic Co-operation and Development (OECD), "OECD.stat."

In exchange for protection by collectivist entities, Japanese employees have little power

What are the problems with Japanese policies from the perspective of a conservative regime? First, Japan has strict termination regulations, but regulations regarding work hours are weaker than in France, and people are forced to work long hours as a quid pro quo for job security. The achievement of work-life balance is an important issue in Japan, but progress has been slow given the worsening of the economic environment. In this regard, the situation is much different from that in France, which has adopted a 35-hour work week and is trying to use regulations to shorten work hours. In addition, the principle of equal pay for equal work, which has been institutionalized in French labor laws, is considerably different from the situation in Japan. ${ }^{14}$

It should also be pointed out that the redistribution function in Japan is weak. Looking back at Figure 1, we see that France engages in a level of redistribution approximately on par with Sweden overall. A comparison of government expenditures in those countries and Japan shows that France spends a much higher share of GDP than Japan on family and employment policies and other expenditures on working-age adults. Japan's low level of expenditures on working-age adults presumably heightens the risks borne by this generation. Even in Japan, a child allowance was introduced in 2010 and efforts are being made to lighten the burden of childrearing costs on families with children. However, as noted earlier, France does not stop at labor-constraining family allowances but rather is quickly increasing access to childcare services and is striving to achieve a balance between labor-constraining policies and labor-promoting policies. Even though Japan has introduced a child allowance, it has also decided to continue allowing the (special) tax deduction for spouses. However, both of these policies have a labor-constraining effect on female labor supply. If greater economic efficiency is to be achieved, urgent efforts are needed to expand childcare services or to eliminate the (special) tax deduction for spouses.

All of this suggests that the problems with Japan's policies as compared with those of a conservative regime are that employees feel compelled to work long work hours and that there is no mechanism for correcting the gap in wages and benefits that exists between full-time and nonfull-time employees. Also, government expenditures on working-age adults, such as unemployment benefits and family allowances, are small, and this creates an environment in which families raising children and the unemployed can easily find themselves exposed to high risks. Thus, the government's redistributive role does not achieve equitable risk sharing across generations, leaving working-age adults particularly vulnerable to risk.

The shift to a conservative regime would require regulations to achieve equity in employment and work-life balance

\footnotetext{
${ }^{14}$ Japan's Labor Standards Law prohibits discrimination by gender, but actual data shows that wage discrepancies between men and women are larger than in other countries. Also, ILO175 (the Part-Time Work Convention) has not been ratified by Japan, as a result of which there has been a considerable delay in getting statutory approval for the equal treatment of full-time and non-full-time workers in terms of wages, training, and other measures.
} 
Shifting to a conservative regime would mean placing employment and family policies at the core of the government's policy strategy for the sake of strengthening the risk sharing functions of collectivist entities such as families and companies.

First, the risks to non-full-time employees would have to be reduced by requiring companies to strictly adhere to the principles of equal pay and equal treatment for equal work.

Second, efforts would have to be made to introduce work sharing or to promote work-life balance by strengthening working hour regulations. This would make it possible for parents to spend more time with their families.

In addition, there is a need to strengthen the redistributive policies of the government, to increase benefits for households raising children and households exposed to employment risk, and to provide better childcare services.

\section{Time for Japan to Reconsider Its Policy Regime}

\subsection{TheRisk-Sharing Functions of Japan's Regime Are Underdeveloped}

Risks are shifted from collectivist entities to individuals outside of those institutions

The following conclusions can be drawn from a comparison of the three policy regimes. Japan shares aspects of both a conservative regime and a liberal regime, but does not have fully developed institutions to allow either of these regimes to function effectively. Thus, deficiencies are apparent when the Japanese regime is compared to either of these regimes. For example, when compared to a model conservative regime, Japan clearly lacks the mechanisms to support such a regime (i.e., redistributive policies) and thus risks are not shared equitably. When compared to a model liberal regime, Japan clearly lacks the mechanisms to support that type of regime; that is, it lacks risk-sharing mechanisms and generous bankruptcy laws that make it possible for people who are having problems repaying their debts to have a second chance. Japan lacks the kinds of safety nets that have been developed in France and the US, and underdevelopment in this area exposes some individuals to certain risks. As a result, in a world in which family patterns are changing considerably due to globalization as well as to the combination of a declining birth rate and population aging and in which people are no longer protected by collectivist entities such as families and companies, risk must be absorbed via government protection or via financial intermediation. Otherwise, opportunities to start over will be limited, exposing individuals to risks.

However, we do not mean to suggest that Japan should return to the system of risk sharing by collectivist entities that existed in the past. While Japan was experiencing steady economic growth, it was possible to compel families and companies to serve a risk sharing role. In recent years, however, under conditions of decreasing household size, an increase in the number of single-person households, and major social and economic upheavals that have put the brakes on growth since the collapse of the bubble, Japan is now in a situation in which it is impossible to expect the risk sharing function to be played by collectivist entities as in the past. If companies are forced to provide employee protection, their very existence will be threatened because employee protection raises employment costs and may ultimately lead to the company's failure. 
Policy regimes change in response to current trends and ideas

It is a mistake to look at policy regimes as being fixed over time in a given country. National policy regimes are continuously changing in response to current trends and ideas. France, which has been used here as an example of a conservative regime, shifted in the mid-1990s from policies that strove to reform the labor market by promoting early retirement to policies that support female employment and encourage a quick return to the workplace after childbirth. ${ }^{15}$ In the $1980 \mathrm{~s}$, France implemented a work sharing arrangement between generations that sought to secure employment opportunities for young people by encouraging the middle-aged and women with children to take early retirement, However, based on the employment strategies proposed in the 1990s by the OECD (1994) and the EU (1997) and given the growing concern about worklife balance, France developed active labor market policies in response to the high unemployment rate among young people and also made a shift in its family policies from providing cash benefits to providing in-kind benefits. Thus, she moved closer toward becoming a social democratic regime.

Conversely, Sweden, which had been a social democratic regime, experienced an economic crisis in the early 1990s and made some changes to its economic policies. The perception at the time those policy changes were implemented was that "the financial crisis of 1990-91 was the result of structural problems built up over time and that it was impossible to overcome the crisis with the adoption of short-term measures alone." ${ }^{16}$ In the late 1990s, Sweden pressed ahead with financial system reforms consisting of substantive pension benefit reductions in response to the aging of the population and also implemented reductions in the number of government workers, deregulation, and tax reform. These were policies that emphasized income redistribution but at the same time emphasized the promotion of economic efficiency.

Even in the US, which has a liberal regime, a health insurance reform act was passed in March 2010 and largely eliminated the problem of the uninsured. This is another example of policy regime transition.

\subsection{No Existing Regime Can Solve All of Japan's Problems at Once}

This section will outline the costs to Japan of transitioning to either of the two regimes and will show that none of the existing regimes will solve all of Japan's problems at once.

Costs of transitioning to a liberal regime: Increase in poverty

If Japan were to transition to a liberal regime, it would see increased poverty. The US is built on the social ideal that anyone with the will to work will be able to find a job and support himself or herself. However, even in the US, which has maintained high growth, there are people who want to work but who lack employment opportunities, and poverty is an omnipresent phenomenon. Considering that competition is likely to grow more fierce in the future between Japan, whose strength is in manufacturing, and the newly developing countries, it is highly likely that the number of unemployed in Japan will increase, and there are limits to the ability of individuals to bear all economic risks. The experience of the US suggests that direct government intervention with respect to redistribution is essential.

\footnotetext{
${ }^{15}$ This discussion is based on Matsumura (2007) and Yanagisawa (2007).

${ }^{16}$ This discussion is based on Nagayama (2006).
} 
Costs of transitioning to a social democratic regime: Increase in the government debt and the swelling of an inefficient public sector

If Japan were to transition to a social democratic regime, the already excessive government debt would increase even further. It would be extremely difficult to get taxpayers to support the implementation of redistributive policies based on the concept of "universalism," ${ }^{17}$ under which there are no income limits on the receipt of benefits, as is the case in Sweden, ${ }^{18}$ because this will cause the government debt to balloon even further and taxpayers are already being asked to bear a heavy burden to service the government debt each year.

In addition, it is highly likely that the Japanese economy would become inefficient if the ratio of public sector spending to GDP were to be increased. In Sweden, one-third of all employees work in the public sector, and the employment absorption capability of the public sector is growing. Some argue that the reason why the expansion of the public sector has not become a problem in Sweden is that the government is transparent. If the Japanese government were to try to follow suit, it would have to simplify its complex administrative structures and to adopt a mechanism that would make it possible for the government to be checked by citizens through the use of an ombudsman system.

Furthermore, providing generous benefits such as those available in Sweden would impede incentives to work and end up creating moral hazard. In Japan, which is experiencing population decline, any weakening of the desire to work among the younger generation will have tremendous costs.

All of this suggests that transitioning to a social democratic regime in which society as a whole bears all risks would have an adverse impact on economic efficiency.

Costs of transitioning to a conservative regime: Intensification of unemployment among young people and an increase in bankruptcy risk

It is highly likely that a shift to a conservative regime in Japan would end up robbing employment opportunities from young workers as a result of efforts to uniformly protect existing employees through regulatory strengthening. ${ }^{19}$ Because the mid-career employment market in Japan is still underdeveloped, virtually all employment adjustments are made in the labor market for new graduates. Research findings show that employment reductions due to a poor economy cause reductions in the hiring of new younger employees, ${ }^{20}$ and this trend would most likely intensify.

\footnotetext{
${ }^{17}$ There are two approaches to the issuance of social welfare benefits: "targeting" and "universalism." The former refers to the transfer of income from high earners to low earners. The latter refers to the guarantee of a certain level of benefits to people of all income levels.

${ }^{18}$ Kato (2001) argues that "The mature welfare states that currently exist operate on a concept of universalism, and as long as citizens are not willing to accept a commensurate burden level, it will not be possible to realize an adequate amount of income redistribution. If political opposition arises in the process of increasing the burden on citizens, redistribution by the welfare state will remain inadequate, and opponents of increasing the burden will seize upon this result to strengthen their own argument, which in turn will further increase opposition to increasing the burden and increasing redistribution through higher social welfare expenditures. This is why, in cases like New Zealand, Canada, and Japan, it is hard to adopt revenue strengthening policies even if there is a budget deficit as long as concerns remain about the increase in the burden placed on citizens. "

${ }^{19}$ As discussed in Yasui (2010), section 2, research has shown that countries that adopt strict termination regulations tend to have lower unemployment frequencies, but once workers become unemployed, they tend to be unemployed for longer periods.

${ }^{20}$ As shown in Yasui (2010), section 3, research has found that economic trends at the time of one's first employment have a long-term impact on employment patterns and wages in Japan.
} 
More fundamentally, there are questions as to whether Japanese companies currently have the ability to withstand economic risks. With exchange rates fluctuating significantly and competition with other Asian countries growing more fierce, adopting conservative policies could very well end up putting Japanese companies at a competitive disadvantage, thus inviting bankruptcies. Under these conditions, there are fundamental limits to the degree of risk sharing, in the form of guaranteed employment, that companies can be expected to bear. ${ }^{21}$ Thus, as an open economy with a declining population and with sluggish performance in the domestic market, Japan would be unable to shift to a conservative regime.

Furthermore, such a regime also has the disadvantage of discouraging the employment of women and is highly likely to result in a loss of economic efficiency. It is important to recognize that in a country such as Japan, where the labor force is declining and where competitiveness must be ensured not through the quantity of its labor force but through its quality, there are high costs associated with implementing policies that impede economic growth, such as those that do not take advantage of the skills of women.

Asking collectivist entities to perform the risk sharing function as they have until now will lead to a weakening of competitiveness and thus should be avoided.

\section{The Path for Japan}

\subsection{Achieving the Socialization of Risk and Emphasizing Fairness and Efficiency Without Making Collectivist Entities Bear All Risks}

This section will discuss the rapidly changing conditions facing Japan and propose the path that Japan should follow, based on the discussion above.

Limits to inducing collectivist entities to function as risk shelters

In the early 21 st century, economic globalization has progressed at a speed that has surpassed expectations. While there is a growing sense of the Asian region's role as "the world's factory" and "the world's market," the Arab-speaking world and Africa are becoming more competitive, and all of this portends profound changes in the economic order that has thus far been centered around the developed nations. At a time when the entire region is embroiled in competition on a global scale, and companies are having to choose the countries and regions that maximize their own profits, regions that have more regulations and higher employment costs than other regions will be less attractive to both domestic and foreign companies. Given these conditions, there are limits to the extent to which Japanese companies, as collectivist entities, can be expected to play the role of risk shelters. Compelling Japanese companies to accept disadvantageous conditions in terms of their international competitiveness will end up either pushing them overseas or reducing their competitiveness to such a degree that they are driven out of business. When thinking about a viable path forward for Japan, it is important that companies not be asked to play an excessive role as a risk shelter. For that reason, Japan should avoid the option of a conservative regime, which focuses on risk sharing through employment regulations. It is not that Japan is turning its back on economic globalization but rather that it is accepting economic globalization as an opportunity for growth.

\footnotetext{
${ }^{21}$ As shown in Aoki, Shimoi, and Nakagomi (2010), section 2, regulations do not help reduce the income gap, if one judges from the Gini coefficient and the poverty rate.
} 
Achieving a society in which risks are distributed equitably

One cannot deny that Japanese society is facing a rapidly declining birth rate and rapid population aging. The government needs to respond to the increased risks posed by changes in the population structure, but there are many problems with the redistribution system currently in place in Japan. For example, recognizing that the aging of the population threatens the viability of the public pension system, the government has passed the risks onto the next generation instead of implementing measures that could be taken now such as increasing the consumption tax. Japan's government expenditures, which could be used to reduce risks for working-age adults and children are, as discussed above, smaller (relative to GDP) than in other developed countries. The fact that the government, which should be responsible for ensuring equitable risk sharing across generations from a long-term perspective, has not been playing this role is a major problem. The government must be made to take more active responsibility for allocating risks more equitably across generations.

However, ensuring an equitable allocation of risk bearing is not something the government can do alone. There are also many things the private sector could do. Private companies could create fair work environments where there is no discrimination by gender, employment status, or age. Because women, non-full-time employees, and senior citizens do not receive equal treatment in the workplace, their risks are not reduced even if they have jobs. Compensating workers based on their skill level or performance will not only enhance their ability to adapt to risk but will also motivate them to work harder, thereby promoting economic efficiency. It is important to create a society in which social risks are not borne disproportionately by the most vulnerable segments of society but are allocated equitably between men and women, between full-time and non-full-time employees, and among children, working-age adults, and the elderly.

Achieving the socialization of risks based on the "targeting" approach

Finally, it is worth noting that Japan has an enormous government debt amounting to a full 200 percent of GDP. Thus, even if taxpayers were asked to bear a heavier burden, the additional revenue would have to be used to service the government debt rather than to finance increases in welfare benefits. There are two approaches to the payment of social welfare benefits: "targeting" and "universalism." The former refers to the transfer of income from high earners to low earners. The latter refers to the guarantee of a certain level of benefits to all individuals regardless of income. In social democratic regimes, which adopt a universalistic approach, the government is relied upon to provide most of the resources used for benefit payments, ${ }^{22}$ and payments are made without income restrictions. However, it would be virtually impossible for Japan to strive to be a welfare state along the lines of Sweden given its current government debt levels. Thus, it would be better for Japan to provide benefits based on the "targeting" approach, which limits the number of benefit recipients as much as possible based on income and other factors. Such an approach makes it possible to achieve risk reductions the mostly efficiently in terms of cost.

\footnotetext{
${ }^{22}$ Strictly speaking, targeting and universalism both reflect methods of benefit distribution and do not have a oneto-one correspondence with a particular regime. For example, Japan's welfare system reflects targeting insofar as it targets households below a certain income, while the public pension system reflects the universalistic approach because it applies to everyone. Based on the relative weights given to each approach in various regimes, liberal regimes tend to reflect the targeting approach, while social democratic regimes tend to reflect the universalistic approach.
} 
Even in the case of child allowances or the provision of free education, measures need to be adopted to impose effective income restrictions, such as limiting benefits only to those with moderate or low incomes.

\subsection{Three Pillars to a Japanese Approach}

Based on the three perspectives above, Japan needs to transition from a system that combines a conservative regime with a liberal regime to a system that combines a social democratic regime with a liberal regime. To do this, Japan's policies in the future should be built on the following three pillars

Pillar 1: The government should ensure an equitable socialization of risk

Japan needs to revise its redistributive policies, which are biased in favor of the elderly, and to create systems in which each generation shares risks equitably. The government should adopt a targeting approach in its transfer programs, paying benefits only to individuals who truly need them and eliminating the administrative discretion enjoyed by government officials when screening benefit applications.

In conservative regimes, which are based on ensuring protection through collectivist entities such as families and companies, risks tend to be borne disproportionately by those who do not belong to such entities. Thus, Pillar 1 suggests that there is a need to adopt the principles of social democratic regimes in which risks are borne equitably by everyone. However, this is not to say that benefits should be expanded needlessly but rather that a targeting approach should be adopted to keep the burden borne by citizens to a minimum.

The following are several specific policies that might be adopted as part of Pillar 1 but are intended to be merely suggestive.

(1) Revise the macroeconomic indexation of public pensions

"Macroeconomic indexation" was adopted as part of the public pension reforms implemented by Japan in 2004. Under this system, benefit amounts are adjusted in response to population decline and increases in life expectancy, but fluctuations in real wages caused by economic shocks are not reflected in the benefits paid to beneficiaries already receiving pensions (current beneficiaries). This structure is not desirable because it does not provide for all generations to bear their fair share of the risk of pension financing. There are several lessons to be learned from Sweden, which has adopted a structure in which all insured persons, including the elderly, bear their fair share of the burden.

Note: Japan's public pension system

Under Japan's public pension system, the benefit amount paid to new beneficiaries receiving pensions for the first time is determined by multiplying a standard amount by the sum of the rate of increase of per capita nominal wages (defined as the sum of monthly income and bonuses net of taxes) and the index-adjustment rate. Thereafter, however, benefits are adjusted only by the 
sum of the inflation rate and the index-adjustment rate. The difference between the rate of increase of per capita nominal wages and the inflation rate is the rate of increase of real wages, but under the current system, fluctuations in real wages caused by economic fluctuations do not affect the benefits received by beneficiaries who are already receiving pensions. Moreover, there is a problematic provision that specifies that benefit amounts are never reduced, meaning that pensioners do not have to bear any downside risk.

(2) Invest in working-age adults and children (education, scholarships, housing subsidies, etc.)

Spreading the risks faced by working-age adults and children across all generations will reduce the risks that these generations have to bear by themselves. More specifically, in-kind benefits such as childcare and long-term care services paid to working-age adults and investments in children's education should be increased, and doing so will lead to increased employment opportunities for both generations in the future.

(3) Develop administrative infrastructure for improving the take-up rate of social welfare programs, introducing a taxpayer number system, etc.

The government should develop the administrative infrastructure needed to ascertain the takeup rate of social welfare programs and to eliminate administrative discretion in the determination of benefits. In addition, the government should introduce a taxpayer number system and "individual accounts" to increase flexibility in the eligibility and timing of various benefits.

(4) Avoid cash benefits and give priority to labor-promoting childcare and long-term care services

Because cash benefits increase household income, they can have a disincentive effect on labor supply. The government should adopt a targeting approach in which it provides assistance only to those who truly need it and establish effective income limits on cash benefits. It should also bolster childcare and long-term care services and implement employment-promoting policies.

Pillar 2: Implement policies that make maximum use of the market mechanism. Simultaneously develop an infrastructure that supports competition in the marketplace.

Japan should implement policies that promote economic efficiency by increasing reliance on the market mechanism (for example, via deregulation) and by strengthening the competitiveness of companies. Moreover, Japan should promote risk sharing through financial markets so that companies and individuals can take risks and create an environment that allows second chances.

The second pillar is not about putting collectivist entities at a competitive disadvantage by requiring them to be unduly responsible for serving as a risk shelter but about focusing on policies that help strengthen business competitiveness. Strengthening competitiveness requires moving away from a conservative regime and toward a liberal regime.

(1) Cultivate new businesses through deregulation

Many fields are attracting attention as new growth industries, including health care, environment, education, and agriculture, but because of the sluggishness of efforts to eliminate 
factors that impede growth and to develop an infrastructure to support those industries, growth prospects in Japan continue to be poor. The government should promote further deregulation with the aim of encouraging firms to cultivate new markets through creative corporate strategies and should also ensure that the risks faced by vested interests that stand to lose from deregulation are borne by society as a whole.

(2) Revise the employment adjustment subsidy system

The current employment adjustment subsidy system poses several problems with respect to fairness and efficiency. First, it gives employers financial incentives to retain workers who are currently employed but no incentives for hiring new workers. By contrast, active labor market policies in Sweden allow for the provision of cash payouts to companies that hire unemployed workers, thereby promoting the employment of new graduates and young workers. Second, the Japanese system allows for the payment of subsidies only to poorly managed and unprofitable companies, whereas in Sweden, companies can receive benefits regardless of their profitability.

Japan's employment adjustment subsidy system gives preferential treatment to current employees, which poses many problems from the perspective of fairness, and moreover, measures that give preferential treatment to unprofitable companies lead to economic inefficiencies. Care should be given to ensure that risks are not borne disproportionately by young unemployed workers, for example, by having the government temporarily shoulder the social insurance contributions of companies, both profitable and unprofitable, that employ young people during periods of economic recession.

\section{(3) Improve the risk mediation capabilities of financial institutions}

Residential assets comprise a large share of household assets in Japan and hence the decline or leveling off of housing prices increases the risks borne by households. For this reason, the government should encourage the further development of the mortgage-backed securities market to enable those risks to be borne more broadly. In addition, there should be an increase in loan products that help reduce the risks of households such as reverse mortgages and non-recourse loans. Such products would allow people to finance their living expenses during retirement by drawing down their housing equity while, at the same time, enabling them to continue living in their own homes, thus making it easier for them to cope with longevity risk.

\section{(4) Raise inheritance taxes}

Raising inheritance taxes would have multiple benefits.

First, raising inheritance taxes would encourage individuals to spend their assets before death (on their own consumption) in order to avoid paying inheritance taxes. This would stimulate consumption and help the economy to recover from the prolonged recession. Second, to the extent that raising inheritance taxes reduces bequests, doing so will reduce the extent to which wealth inequalities are passed on from generation to generation and help create a fair society with a level playing field. Third, to the extent that increasing inheritance taxes increases tax revenue, doing so will contribute to fiscal reconstruction and help secure the resources needed to finance long-term care services. Fourth, if inheritance taxes are increased not by raising tax rates but by taxing land at its market value (it is currently greatly undervalued for inheritance tax purposes), raising them will make the tax more equitable across asset types.

In Japan, children have traditionally received bequests as a quid pro quo for caring for, and providing financial support to, their aged parents (see, for example, see Horioka, 2008), meaning 
that children are the ones who bear their parents' longevity risk (the risk that their parents live a long life). Thus, even though raising inheritance taxes might reduce the amount of bequests that children would receive, it would also mean that children would not have to support their parents during old age, meaning that they would no longer have to bear their parents' longevity risk. If long-term care services were expanded, as proposed in the first pillar above, and if reverse mortgages and other similar financial products were developed, as proposed in item (3) above, longevity risk would be borne by society as a whole rather than by parents themselves or by their children.

(5) Reduce the cost of corporate and personal bankruptcies

To achieve a more efficient distribution of resources through corporate competition, Japan needs to reduce the cost of corporate bankruptcies, to revise its corporate bankruptcy and recovery system, and to improve the implementation of this system to allow companies to move more quickly to implement corporate restructuring and recovery. Turning to personal bankruptcies, when individuals declare personal bankruptcy in Japan, they are required to relinquish virtually all of their assets and thus it is very difficult for them to start anew. We need to increase the amount of cash that individuals are allowed to keep when they declare bankruptcy and to allow them to keep real assets up to a certain limit.

Pillar 3: Do not guarantee uniform employment protection through employment regulations but allow individuals to choose the work patterns that best suit them.

Japan should create a society in which individuals are able to make decisions on their own, choosing combinations of risk and return that are suitable for them, rather than being protected by regulations. At the same time, Japan should create an equitable society without discrimination due to gender, employment status, or age.

them to choose the combination of risk and return that best suits them. It also reflects the need to strengthen individuals' capacity to cope with risk by ensuring a fair society. What we are proposing is not a conservative regime in which employment is protected via regulations but a fair society in which working individuals are respected.

(1) Promote diversification in the types of employment contracts

Ando (2009) advocates allowing employers and employers to freely conclude employment contracts that specify the duration and location of employment, job responsibilities, etc. In Japan, only two types of contracts are allowed: long-term (permanent) contracts and limitedterm contracts, generally of up to three years. In reality, however, since risk and return preferences vary by individual, efforts should be made to allow individuals, even those working at the same company, to choose from a full menu of fairly designed options that offer individuals a combination of employment terms (risk and return) that suits them. We advocate deregulating termination regulations and wage structures so that workers can choose between employment contracts in which stable employment at low wages is guaranteed and employment contracts in which there is a high possibility of termination but wages are paid based on performance. 
(2) Achieve a society in which people have fair access to work regardless of gender, employment pattern, or age

Achieving a society in which people have fair access to work regardless of gender, employment pattern, or age will enable all individuals to choose a work pattern that suits their own life plan and fulfills their dreams and to achieve work-life balance. This goal could be achieved by levying penalties on employers that violate the law and introducing an ombudsman system to strengthen monitoring functions.

Our proposals can be summarized as follows:

Figure 2: Taxonomy of Japan's Policy Regime

$\underline{\text { Status Quo }}$

Conservative Regime

Collectivist entities are required to serve as risk shelters, but those who do not belong to such entities are exposed to risk.
Our Recommendation

Respect the autonomy of working people and allow individuals to choose their own work pattern.

\section{Social Democratic Regime}

Distribute risks equitably across society. Create a fair society in which individuals are better able to bear risks.

\section{Liberal Regime}

The government plays only a small

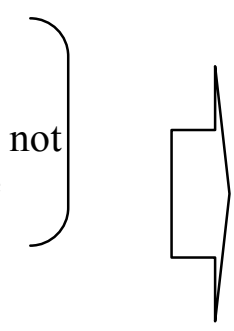

Liberal Regime

$\left(\begin{array}{c}\text { Achieve economic growth } \\ \text { through deregulation. Develop an } \\ \text { infrastructure that supports } \\ \text { competition in the marketplace. }\end{array}\right)$

\section{Conclusions}

In this article, we pointed out some problems associated with the socialization of risk in Japan from the perspective of policy regimes, and based on the analysis presented, we made suggestions regarding the direction in which Japan should start heading. When positioned within the policy regime framework, Japan's policies seem to have the characteristics of a liberal regime insofar as the government's redistributive role is limited and reliance on the market mechanism is high. However, Japan's reliance on income distribution through the mutual assistance provided by families and companies is more characteristic of conservative regimes. Thus, Japan has features of both of these regimes but lacks the mechanisms needed for either regime to function effectively and lacks mechanisms for risk sharing. The incompleteness of 
either regime in Japan means that those individuals who do not belong to any collectivist entity are exposed to risks.

However, the costs of transitioning to any of the three existing regimes would be prohibitively large. Thus, Japan needs to find its own path toward its own ideal (and heretofore non-existent) policy regime. There is no need to think of a policy regime as being rigid or unchanging. Even in the countries used as examples here (the US, France, and Sweden), policy regimes have changed as times have changed.

The direction that Japan must take can be condensed into three pillars. First, the government should promote the equitable socialization of risk. Second, the government should implement policies that allow the market mechanism to operate to the fullest extent possible and should, at the same time, develop an infrastructure that supports competition in the marketplace. Third, Japan should not ensure uniform protection through employment regulations but allow individuals to choose the work patterns that best suit them.

The key here is that all of these pillars must be implemented simultaneously. Even if some of the policies of various foreign countries were to be introduced, they will be meaningless if no thought is given to the political background within which they were adopted. We recommend revising the current employment adjustment subsidy system but, for several reasons, do not suggest the introduction of active labor market policies like those currently being implemented: because the efficacy of such policies is unclear, because Japan's redistributive policies are not very extensive, and because it is unlikely that large numbers of people will lose their desire to work as a result of benefits provided by the government.

Japan needs to implement a coherent package of policies rather than a patchwork of different policies. If she does not do so, it is difficult to be optimistic about Japan's future. 


\section{References}

Abe, Naohito (2010), "Income Risks Faced by Contemporary Japanese Households, Part 1: Income Risk Trends in Japan," The Japanese Economy, vol. 37, no. 3 (Fall).

Ando, Munetomo (2009), "Roudou ru-ru no saikouchiku to shin shisutemu he no ikou purosesu-Koyou keiyaku no tayouka to shin seido dounyū katei no meijitekina kentou ga hitsuyou" [The Reconstruction of Labor Rules and the Process of Transitioning to a New System: The Need for Investigations into the Diversification of Employment Contracts and the Process of Introducing a New System], Shüshin koyou to iu gensou o suteyo--Sangyou kouzou henka ni atta koyou shisutemu ni tenkan wo [Discarding the Illusion of Lifetime Employment: Shifting to an Employment System that Accommodates Changes in the Industrial Structure], pp. 47-61, National Institute for Research Advancement.

Aoki, Shuhei (2010), "Income Risks Faced by Contemporary Japanese Households, Part 2: Current Status and Long-Term Trends in the Income Gap and Income Risks Overseas," The Japanese Economy, vol. 37, no. 3 (Fall).

Aoki, Shuhei; Shimoi, Naoki; and Nakagomi, Kimiya (2010), "Policy Response to Risks in Foreign Countries," The Japanese Economy, vol. 37, no. 3 (Fall).

Arai, Mitsuyoshi (2002), Amerika no fukushi kokka seisaku--Fukushi kirisute seisaku to koureishakai nihon he no kyoukun [Welfare State Policies in the US: Welfare-Cutting Policies and Lessons for Japan's Aging Society], Kyushu University Press.

Bertola, Giuseppe, Richard Disney, and Charles Grant (2006), "The Economics of Consumer Credit," The MIT Press.

Coate, Stephen and Glenn Loury (1993), "Will Affirmative-Action Policies Eliminate Negative Stereotypes?" American Economic Review, Vol. 83, pp. 1220-1240.

Esping-Andersen, Gosta (1990), "The Three Worlds of Welfare Capitalism," Princeton University Press.

Esping-Andersen, Gosta (1999), "Social Foundations of Postindustrial Economies," Oxford University Press. (Translated by Masao Watanabe and Eiko Watanabe (2000), Posuto kougyou keizai no shakaiteki kiso--Shijou / fukushi kokka / kazoku no seiji keizaigaku, Sakurai Shoten.)

Ferguson, Niall (2008), The Ascent of Money: A Financial History of the World (New York: Penguin Press, 2008).

Forster, Michael and Macro Mira d'Ercole (2005), Income Distribution and Poverty in OECD Countries in the Second Half of the 1990s, OECD Social, Employment and Migration working papers. 
Horioka, Charles Yuji (2008), "Nihon ni okeru isan douki to oyako kankei: Nihonjin ha rikoteki ka, ritateki ka, ouchouteki ka?" [Bequest Motives and Parent-Child Relations in Japan: Are the Japanese Selfish, Altruistic, or Dynastic?] in Charles Yuji Horioka and the Institute for Research on Household Economics, eds., Setainai bunpai / sedaikan iten no keizai bunseki [An Economic Analysis of Intrahousehold Distribution and Intergenerational Transfers], pp. 33-51, Minerva Shobo.

Kato, Junko (2001), "Fukushi kokka no zeishū kouzou no hikaku kenkyū: OECD 18 kakoku to shinkou sangyoukoku" [Comparative Analysis of the Tax Collection Structures of Welfare States: The OECD 18 and the Newly Industrialized Nations], Discussion Paper No. 40, Hitotsubashi University Intergenerational Problems Research Project.

Matsumura, Fumito (2007), "Furansu no shitsugyou hoken to koyou seisaku" [French Unemployment Insurance and Employment Policies], Kaigai shakai hoshou kenkyū [Research on Social Welfare Overseas], Winter 2007, No. 161.

Nagayama, Yasuhiko (2006), "Sue-den keizai no kouzou kaikaku--Atarashii fukushi shakai moderu he" [Structural Reform in the Swedish Economy: Toward a New Welfare Society Model], Shobi University Journal of General Policy Research, Vol. 11 (March 2006), pp. 33-51.

Revillard, Anne (2006), "Work/Family Policy in France: From State Familialism to State Feminism?” International Journal of Law, Policy and the Family, Vol.20, pp.133-150.

Yamada, Ryohei (2006), Beikoku no kaisei hasan hou no kaisei ni tsuite [Revisions to the Bankruptcy Code in the US], Japan External Trade Organization (JETRO), New York Center.

Yamaguchi, Kazuo (2008), "Danjo no chingin kakusa kaishou he no michisuji: Toukeiteki sabetsu no keizaiteki fugouri no rironteki jisshouteki konkyo" [Path to the Elimination of the Wage Gap Between Men and Women: The Theoretical and Empirical Basis for the Economic Irrationality of Statistical Discrimination], Report for a Special Cabinet Committee (July 1, 2008).

Yanagisawa, Fusako (2007), "Furansu ni okeru shoushika to seisaku taiou" [Birthrate Decline and the Policy Response in France], Reference, November 2007.

Yasui, Kengo (2010), "Thinking about Measures to Address Employment Risk: A Survey of Empirical Research,” The Japanese Economy, vol. 37, no. 3 (Fall). 